ВПРОВАДЖЕННЯ ТРЕНІНГІВ ПРИ ФОРМУВАННІ ГОТОВНОСТІ

МАЙБУТНІХ ФАХІВЦІВ З ГОТЕЛЬНО-РЕСТОРАННОЇ СПРАВИ ДО РЕАЛІЗАЦІЇ ФУНКЦІЙ З ПРОФЕСІЙНОЇ ДІЯЛЬНОСТІ

\title{
IMPLEMENTATION OF TRAINING IN FORMING THE READY FOR FUTURE PROFESSIONALS FROM HOTEL AND RESTAURANT BUSINESS TO REALIZATION OF PROFESSIONAL ACTIVITY FUNCTIONS
}

УдК 378.147:81'271:640.4(045) DOI https://doi.org/10.32843/26636085/2019.21.3-26

\section{Трофрімук К.В.,}

канд. пед. наук

доцент кафедри туризму

та готельно-ресторанної справи

Класичного приватного університету
Статтю присвячено пошуку ефрективних способів використання тренінгів при підготовці майбутніх орахівців з готельно-ресторанної справи до професійної діяльності. Проаналізовано основні завдання та принципи тренінгів, які сприяють самореалізації особистості та покращують якість професійного спілкування. Наведено тренінги, які стали найбільш успішними при формууванні профресійних навичок та професійного спілкування у майбутніх фрахівців з готельноресторанної справи, під час яких вирішуються питання розвитку особистості, формування комунікативних навичок та надання психологічної підтримки.

Доведено, що головною для успіху у спілкуванні майбутніх фрахівців $є$ готовність орієнтуватися на іншу людину, визнавати иінність їі особистості, брати до уваги інтереси партнера. У групах тренінгів з ділового спілкування під час занять обов'язково проводяться групові дискусії, рольові ігри, для яких використовуються ситуації, що відповідають змісту основної професійної діяльності учасників занять. В умовах програвання профресійних ситуацій студентам надається можливість вільного вибору вирішення проблем взаємодії людини з людиною або групою людей та створення позитивного середовища під час спілкування. Відповідно до оцінок діяльності та самооцінки своїх дій студент зможе покращити професеійні вміння та спілкування, які безпосередньо впливають на професійну діяльність майбутнього фрахівця.

у ході дослідження було виявлено, що розроблені та впроваджені тренінги для фрормування професійних навичок у майбутніх фахівців з готельно-ресторанної справи, які моделювали встановлення контактів, ефрективно сприяють розвитку різних фрорм професійної діяльності та методів спілкування. Ключові слова: тренінгові технології, комунікативні тренінги, срахівці готельно-ресторанної справи, профресійна підготовка, психологічна підтримка.
The article is devoted to finding effective ways to use training in preparing future professionals in the hotel and restaurant business for professional activity. The basic tasks and principles of trainings that promote self-realization of the individual and improve the quality of professional communication are analyzed. The trainings that became the most successful in the formation of professional skills and professional communication of future specialists in the hotel and restaurant business, during which the issues of personality development, the development of communication skills and the provision of psychological support are given.

It is proved that the main for success in communication of future specialists is the willingness to focus on another person, to recognize the value of his personality, to take into account the interests of the partner. In business communication training groups, group discussions, role-playing games, which use situations that are relevant to the content of the main professional activity of the participants, are mandatory. In such circumstances, playing professional situations gives students the opportunity to freely choose to solve problems of interaction of a person with a person or a group of people and to create a positive environment during communication. According to the evaluation of his activity and selfassessment of his actions and comparisons, the student will be able to improve professional skills and communication, which directly affects the professional activity of the future specialist. Developed and implemented trainings to build professional skills for future hotel and restaurant professionals who modeled contacts and effectively facilitated the development of various forms of professional activity and communication methods.

Key words: technology training, training in communication, experts hotel and restaurant business, training, culture of Professional communication
Постановка проблеми в загальному вигляді. Сучасний етап розвитку освіти пов'язаний з необхідністю розв'язання проблеми підвищення інтелектуального рівня, пізнавального і творчого потенціалу студентів, тому актуальною стає проблема пошуку таких фрорм навчання, які відповідатимуть новим освітнім потребам та сприятимуть формуванню професійної компетентності майбутніх фрахівців готельно-ресторанної справи.

Нині в Україні вдосконалюється система підготовки фрахівців 3 готельно-ресторанної справи відповідно до вимог професійної освіти. Під час професійної підготовки фрахівців даної галузі у вищій школі обов'язковою умовою навчання і майбутньої профресійної діяльності є знання професійних навичок та володіння професійним спілкуванням.

Сорормувати профресійні навички та володіння майстерністю спілкування у студентів можна завдяки використанню тренінгів, під час яких вирішуються питання розвитку особистості, фрормування комунікативних навичок та надання психологічної підтримки.

Аналіз останніх досліджень і публікацій. Аналіз педагогічної літератури засвідчує, що досвід використання тренінгових підходів вивчали такі учені: І. Вачков, Т. Григор'єва, Г. Ковальова, 
Л. Петровська, В. Семиченко, Є. Сидоренко та інші. Проблеми спілкування досліджувались у працях Н. Бабич, А. Бодальова, В. Грехнєва, О. Леонтьєва, С. Макаренка, В. Сластьоніна та ін. Проте у наукових працях недостатньо висвітлене питання використання тренінгів при формуванні профресійних навичок майбутніх фрахівців 3 готельно-ресторанної справи.

Виділення не вирішених раніше частин загальної проблеми. Сорормувати професійні навички та майстерність спілкування у студентів можна за допомогою використання тренінгів, під час яких вирішуються питання розвитку особистості, фрормування комунікативних навичок та надання психологічної підтримки.

Мета статті - розглянути особливості використання тренінгів при фрормуванні навичок професійної майстерності та удосконаленні спілкування у майбутніх фрахівців готельно-ресторанної справи.

Виклад основного матеріалу. Науковці доводять, що тренінгові технології сприяють самореалізації особистості та покращують якість професійного спілкування. Застосування різноманітних тренінгів у навчально-виховному процесі зумовлене їх ефективністю, в результаті чого відбувається орормування та розвиток умінь і навичок [2]. Учений І. Вачков визначає тренінг як активний метод практичної психології, що використовується для фрормування навичок самопізнання та саморозвитку [2, с. 21]. Як доводить К. Корольова, в результаті психологічних тренінгів вдосконалюється особиста поведінка та змінюється система взаємовідносин з соціальним оточенням [5, с. 76]. Отже, психологічний тренінг використовується для фрормування навичок самопізнання, рефлексів, зміни ставлення до себе та інших, а також вироблення навичок саморегуляції і покращення емоційної поведінки.

Успіх в роботі будь-якого підприємства залежить від злагодженої роботи його колективу, командної роботи. Наскільки ефективним буде робота готельного підприємства, наскільки задоволеними будуть гості, напряму залежить від поведінки персоналу, вміння вчасно та непомітно для самого гостя виконати будь-яке його прохання. 3 огляду на це актуальним в наш час $є$ виховання та підтримання високого професійного рівня, а також ефрективне управління на підприємствах гостинності.

На думку Х.Ю. Роглєва, тренінги у галузі гостинності - це ефективне профресійне навчання з надання готельних послуг за оригінальними програмами з актуальною тематикою. Тренінги дають персоналу нові ідеї, методи, підходи у вирішенні стратегічних і оперативних завдань, у підвищенні якості обслуговування. Вони надають допомогу у вирішенні питань і проблем, що виникають у процесі роботи з управління персоналом, роботи
3 маркетингом, комунікаціями, продажами і фрінансами [7].

Залежно від видів тренінгів (тренінг ділового спілкування, тренінг поведінки, тренінг креативності, тренінг сенситивності тощо) основними цілями, які об'єднують різні за напрямом і змістом тренінгові групи, є такі:

1) допомога в дослідженні і вирішенні психологічних проблем:

2) покращення психологічного здоров'я;

3) вивчення психологічних основ спілкування;

4) розвиток самосвідомості з метою особистої зміни і корекція поведінки;

5) сприяння особистому зростанню та розвитку [3, с. 60].

Вчені виокремлюють такі критерії ефективності щодо результатів проведення тренінгів:

- підвищення аутопсихологічної, психологічної та професійної компетентності;

- перехід на новий рівень профресіоналізму;

- розвиток готовності до саморозвитку та самореалізації у професійної діяльності;

- створення оптимістичної професійної перспективи та оволодіння прийомами (технологіями) профресійного самозбереження;

- переборювання деструктивних професійних змін та попередження втрати значення професійної діяльності [1; 4].

На думку Л. Петровської [8], Д. Рамендика [10], Е. Сидоренка [12] та інших дослідників, основною метою соціально-психологічного тренінгу є підвищення компетентності у сфрері спілкування. Тренінг ділового спілкування трактується як вид соціально психологічного тренінгу, спрямований на розвиток вмінь та навичок, корекцію та фрормування установок, необхідних для успішного спілкування в умовах профресійної діяльності. Головною для успіху у спілкуванні $€$ готовність орієнтуватися на іншу людину, визнавати цінність їі особистості, брати до уваги інтереси партнера. У групах тренінгів з ділового спілкування під час занять обов'язково проводять групові дискусії, рольові ігри, для яких використовуються ситуації, що відповідають змісту основної профресійної діяльності учасників занять [7, с. 409].

Дослідник Д. Рамендик наголошує, що тренінги зі спілкування допомагають учасникам уникнути помилок і знизити гостроту емоційного стресу, що виникає при труднощах у спілкуванні. Тренінги зі спілкування використовуються 3 метою навчити студентів ефективної поведінки в різних ситуаціях спілкування та розвивати в них відповідні навички [9, с. 7]. Результатом успішного тренінгу зі спілкування повинна стати адекватна самооцінка, зміна стратегії поведінки та подолання будь-яких перешкод у спілкуванні.

Нині досвід доводить, що рівень професійної освіти майбутніх фрахівців з готельно-ресторанної 
справи, в якій професійна культура спілкування визначає поняття «професійна компетентність», повинен бути забезпечений педагогічною системою профресійної освіти. Метою впроваджених тренінгів є фрормування готовності майбутніх фахівців 3 готельно-ресторанної справи до реалізації ффункцій $з$ профресійної діяльності спілкування. На основі надання їм психологічної й педагогічної допомоги і підтримки міжособистісного та внутрішньогрупового спілкування заняття $€$ спрямованими на створення свідомих комунікативних вмінь та на фрормування реалістичної впевненості в собі. Студенти оволодівають вміннями вислухати і зрозуміти іншого та висловити свою думку та побажання так, щоб перекласти дії на співрозмовника і зробити його своїм партнером.

Впроваджуючи на заняттях тренінги зі спілкування, ми визначили такі завдання:

- розвиток комунікативних навичок, які зміцнюють соціальні зв'язки;

- розвиток соціального уявлення про людину, здатності до емпатії, співпереживання, створення у вихованців відчуття, що їх розуміють і приймають;

- розвиток здатності до самоаналізу, самопізнання, навичок ведення позитивного внутрішнього діалогу про самого себе;

- усвідомлення своєї позиції у спілкуванні, розуміння й аналіз своєї установки під час сприймання різних людей;

- оволодіння способами вираження своїх емоцій (як позитивних, так і негативних);

- навчання конструктивним способам виходу з конфліктних ситуацій, вираженню своїх почуттів і переживань без конорліктів;

- фрормування й розвиток здібностей прогнозувати поведінку іншого, передбачати свій вплив на нього;

- фрормування активної соціальної позиції учасників і розвиток у них здатності ефективно взаємодіяти з оточуючими;

- розвиток уміння й потреби в пізнанні інших людей, гуманному ставленні до них.

При фрормуванні професійного спілкування у майбутніх фрахівців 3 готельно-ресторанної справи ми використовували тренінги навичок спілкування, які описані у роботах Д. Рамендика [9], І. Вачкова [3], Б. Матвєєва [7]. Серед тренінгів підготовки до професійного спілкування особливо успішними стали такі:

1) вправи для розвитку навичок спілкування («Впевнені, невпевнені та агресивні відповіді» (Д.М. Рамендик), «Що приємно більшості людей?» (І.В. Вачков), «Комплімент» (Б.Р. Матвєєв), «Організація діалогу» (І.В. Вачков), «Відгадай почуття» (В.Г. Ромек));

2) вправи для розвитку упевненості в собі і навичок переконання. фрормування впевненості в собі - важлива частина особистого в цілому і вміння спілкуватися зокрема. Це такі вправи: «Досвід впевненості поведінки» (Д.М. Рамендик), «Підбір фрраз для контакту» (Д.М. Рамендик), «Як сказати «ні» (Д.М. Рамендик), «Захисна промова» (Д.М. Рамендик), «Дар переконання» (І.В. Вачков));

3) вправи на спільне виконання завдань («Корабельна аварія» (Б.Р. Матвєєв), «Катастрофра в пустелі» (І.В. Вачков), «Три господарки» (Б.Р. Матвєєв), «Ідентифрікація 3 проблемою». (Д.М. Рамендик));

4) вправи на поведінку в конорліктних ситуаціях, при агресії, маніпуляції («Поведінка в конфрлікті» (В.Г. Ромек), «Спілкування 3 людьми 3 аномальною поведінкою або з обмеженими можливостями» (Д.М. Рамендик), «Вміння передавати інфрормацію» (І.В. Вачков), «Почуття» (Д.М. Рамендик), «Аномальна поведінка» (Д.М. Рамендик).

Використання даних тренінгів базувалося на загальноприйнятих принципах діяльності учасників тренінгу. Зокрема, це такі принципи:

1) принцип активності, який передбачає залучення всіх учасників до роботи;

2) принцип творчої позиції, який полягає у тому, що у процесі заняття постійно створюються ситуації, у яких учасникам доводиться самим розв'язувати проблеми, які виникають при спілкуванні людей, та долати мовні бар'єри;

3) принцип корегування та усвідомлення своєї поведінки, який передбачає засвоєння та усвідомлення інформації та порад, які людина отримує від інших учасників групи відносно своєї поведінки;

4) принцип пізнання, що в умовах спілкування забезпечує есективність та динаміку пізнавальних процесів набагато вищі за ті, які характеризують ці процеси в умовах ізольованої діяльності;

5) принцип щирості та довіри по відношенню до партнерів та щодо самого себе. Цей принцип визначає прийняття до уваги інтересів співрозмовника та прагнення до співчуття. Реалізація цього принципу створює у групі атмосферу довіри, відкритості, яка дозволяє учасникам експериментувати зі своєю поведінкою, не соромлячись помилок.

Спираючись на досвід науковців, ми розробили та впровадили тренінги для фрормування професійних навичок у майбутніх фрахівців 3 готельноресторанної справи, які моделювали встановлення контактів та ефективно сприяли розвитку різних фрорм профресійної діяльності та методів спілкування.

Тренінг «СПіР» (служба прийому і розміщення) забезпечує реалізацію таких цілей: тренування навиків активного слухання; подолання психологічних бар'єрів при спілкуванні; оволодіння нормами мовленнєвого етикету; покращення логічного та 
послідовного висловлювання; розвиток уважності до опонентів та співробітництва $з$ клієнтами.

Тренінг «Бронювання» (попереднє замовлення за телефоном) сприяє розвитку таких вмінь та навичок: чітко та правильно фрормулювати свою думку; впевнено пропонувати різні варіанти для замовлень; переконувати співрозмовника; вникати у подробиці сказаного; уважно слухати клієнта, ставлячи уважні запитання, але не перебиваючи його.

Тренінг «Офіціант» допомагає майбутнім фрахівцям створювати невимушену атмосферу при спілкуванні, справляти позитивне враження на клієнтів, спонукати гостей до прийняття рішення у виборі замовлень, підбадьорювати та підтримувати співрозмовників у їх виборі, коректно висловлювати свої зауваження чи сумніви.

Проведення поданих тренінгів дає змогу створити робочий простір, спонукати студентів до творчості і прояву індивідуальної ініціативи та допомагає подолати професійні та мовні бар'єри. При цьому відбувається активний обмін інформацією між учасниками. Студент випробовує себе 3 різних позицій, а саме позиції адміністратора готелю, гостя, офріціанта, клієнта, глядача та ін., тобто він може пережити різні для нього ролі. Інші студенти належно можуть оцінити його роботу та дії (як позитивно, так і з критичної точки зору). В умовах програвання професійних ситуацій студентам надається можливість вільного вибору щодо вирішення проблем взаємодії людини 3 людиною або групою людей та створення позитивного середовища під час спілкування. Відповідно до оцінок діяльності та самооцінки своїх дій студент зможе покращити профресійні вміння та спілкування, яке безпосередньо впливає на професійну діяльність майбутнього фрахівця. При спілкуванні під час тренінгу учасники слідкують за манерами поведінки, виразом обличчя, фрізичним напруженням, тоном та тембром голосу та жестикуляцією, тобто набувають навичок невербального спілкування.
Висновки. Отже, під час проведення тренінгів створюються умови для фрормування нових та більш ефрективних навичок професійної діяльності та підвищується компетентність особистості у спілкуванні. Профресія фрахівця готельно-ресторанної справи передбачає активне спілкування, а комунікативна компетентність $€$ частиною профресійної компетентності профресії типу «людина людина».

\section{БІБЛІОГРАФІЧНИЙ СПИСОК:}

1. Большаков В.Ю. Психологический тренинг. Санкт-Петербург : Питер, 2006. 256 с.

2. Вачков И.В. Основы технологии группового тренинга. Психотехники : учебное пособие. 2-е изд., перораб. и доп. Москва : Изд-во «Ось - 89», 2000. $224 \mathrm{c}$.

3. Вачков И.В. Психология тренинговой работы: Содержательные, организационные и методические аспекты ведения тренинговой группы. Москва : Эксмо, 2007. 416 с.

4. Зеер Е.Ф. Психология профрессионального образования. Москва : Флинта, 2003. 125 с.

5. Корольова К.В. Психологічний тренінг як засіб особистісного зростання. Соціальна психологія. 2008. № 3.

6. Матвеев Б.Р. Развитие личности подростка. Санкт-Петербург. Речь. 2005. 220 с.

7. Мунін Г.Б., Карягін Ю.О., Роглєв Х.Й. та ін. Менеджмент готельно-ресторанного бізнесу : навч. пос. Київ : Кондор, 2008. 460 с.

8. Петровская Л.А. Компетентность в общении. Москва : Изд-во МГУ, 1989. 216 с.

9. Психологический словарь / под общ. ред. А.В. Петровского, М.Г. Ярошевского. 2-е изд., исп. и доп. Москва : Политиздат, 1990. 494 с.

10. Рамендик Д.М. Тренинг личностного роста. Москва : ФОРУМ ; ИНФРА-М, 2007. 176 с.

11. Ромек В.Г. Тренинг уверенности в межличностных отношениях. Санкт-Петербург : Речь, 2003. 175 C.

12. Сидоренко Е.В. Тренинг влияния и противостояния влиянию. Санкт-Петербург : Речь, 2002. $256 \mathrm{C}$. 